\title{
Purchasing Power Parity in Commonwealth of Independent States
}

\author{
Asst. Prof. Dr. Gülçin Güreşçi Pehlivan (Dokuz Eylül University, Turkey) \\ Ph.D. Candidate Esra Ballı (Çukurova University, Turkey) \\ Prof. Dr. Muammer Tekeoğlu (Çukurova University, Turkey)
}

\begin{abstract}
The Purchasing Power Parity suggests that differences in relative prices in two countries move together with nominal exchange rates in the long run. This study examines the validity of PPP as transition economies for Commonwealth of Independent States (CIS). Purchasing Power Parity holds only when the real exchange rate is stationary in the equation. To test the stationary, we used both time series and panel data analysis. Testing unit root both with time series and panel data in this study, provides us double check of the results. We also test the cross sectional dependence to choose the appropriate panel unit root test. Our test statistics indicate that there is cross section dependence between countries. Hence, one needs to take into consideration the cross section dependence while undertaking unit root tests. Otherwise, the results would be biased. ADF and KPPS indicate that PPP cannot be accepted for the countries except for Russia. According to the panel unit root test results indicate that PPP does not hold for Armenia, Belarus, Georgia, Kazakhstan and Kyrgyzstan except for Russia.
\end{abstract}

\section{Introduction}

Purchasing Power Parity (PPP) is of importance for economics. Several empirical studies have implemented to test the validity of PPP hypothesis for different countries. As Commonwealth of Independent States (CIS)' countries are in the process of transition for the market economy it is important to examine whether PPP holds for these countries because of its economic implications. CIS' liberalization programs started in the early 1990s. Most countries dealt with the drastic increases in budget deficits, debts and inflation. Several institutional and structural adjustments that occurred in transition countries have undergone several phases of economic changes.

There is a great deal of literature on PPP and some of the studies with the several methodologies have implemented to test the validity of PPP in the long run Empirical evidence on the stationarity of real exchange rates for transition economies is abundant. The most common approach in testing the PPP hypothesis is to utilize the unit root test(s) on the real exchange series Choudhry (1999) examined PPP for Poland, Romania, Russia and Slovenia using us fractional and Harris-Inder cointegration tests from 1991 to 1996/97. He found some evidence to support relative PPP for Russia and Slovenia. Barlow (2003) investigated three transition economies including Poland, the Czech Republic and Romania to examine the PPP using cointegration analysis for the period of April 1994 to December 2000. He found mixed results for these countries.

Payne et al. (2005) examined the validity of PPP for a transition economy, Croatia, using monthly data from the period of January 1992 to October 1999. They did not find evidence in support of PPP for Croatia. Chang and Tzeng (2011) tested the asymmetric adjustment on long-run purchasing power parity in nine transition countries including Russia between January 1995 and December 2008 period using a threshold cointegration test. They found strong evidence of long-run PPP for these countries and the adjustment mechanism was asymmetric.

Acaravci and Ozturk (2010) examine the validity of the PPP in eight transition countries for monthly data from 1992 to 2009. They found weak evidence to support long-run PPP. Tkalec and Vizek (2011) examined the validity of PPP hypothesis for Croatia utilizing Johansen cointegration and threshold cointegration tests from January 1996 to October 2010. They found that absolute power parity condition holds in the long run. He et al. (2013) test the long-run purchasing power parity in the transition economies, which are Bulgaria, the Czech Republic, Hungary, Latvia, Lithuania, Poland, Romanian, and Russia, for the period from January 1995 to October 2011 using panel unit root test. The results show that the PPP does not hold for Hungary, the Czech Republic and Russia.

Lu et al. (2012) examine the validity of long-run Purchasing Power Parity (PPP) for a sample of transition countries including Russia for the period from January 1995 to December 2008 using autoregressive distributed lag test for threshold cointegration. They found an evidence of PPP for Estonia, Hungary, Poland, Romania and Russia. Hasanov and Teletar (2009) test the validity of PPP for CIS countries using the annual output growth rates and inflation rates for the period from 1992 to 2005. They found evidence that support PPP for these economies. Varamini and Lisachuk (1998) examined PPP for Ukraine using monthly data from March 1992 to August 1996 utilizing Engle-Granger test. They found some evidence in favor of PPP.

Solakoglu (2006) examined the validity of PPP for 21 transition countries for 12 years of unbalanced annual data using panel unit root tests. She found that that PPP holds for Armenia, Azerbaijan, Georgia, Kazakhstan, Kyrgyzstan, Moldova, Russia and Ukraine. Doganlar (2006) tested the PPP for Azerbaijan, Kazakhstan and Kyrgyzstan using monthly data from 1995 to 2002 employing the cointegration analysis. He found no evidence 
for PPP for these countries. Apergis (2003) examined PPP for Armenia using monthly data from 1993 to 1996 utilizing OLS test. He found no evidence in favor of PPP.

Sideris (2006) tests PPP for 17 European transition countries, including Belarus, Georgia, Moldova, Russia and Ukraine utilizing the Johansen cointegration methodology for the period of 1995 to 2004 for CIS countries. He found no evidence for Belarus, Georgia, but weak evidence for Moldova, Russia and Ukraine. Bekő and Boršič (2007) examined PPP for the Czech Republic, Hungary and Slovenia vis-à-vis Austria, Germany, France and Italy with using monthly data from January 1992 to December 2006. They found no evidence of PPP.

Chang et al. (2011) examine the validity of long-run purchasing power parity (PPP) using nonlinear cointegration for nine transition countries, Bulgaria, the Republic of Czech, Estonia, Hungary, Latvia, Lithuania, Poland, Romania, and Russia, from January 1995 to December 2008. They found evidence in favor for PPP for all countries. Hung and Weng (2011) test the validity of the PPP for Azerbaijan, Kyrgyzstan and Kazakhstan visà-vis Russia utilizing cross-section correlations of panel unit root tests. They found significant support for the PPP for these countries when taking into consideration of the cross-sectional dependence on panel unit root tests.

The paper is organized as follows. The next section explains the theoretical model on purchasing power parity the third section presents data and empirical methodology, the fourth concludes.

\section{Theoretical Model on Purchasing Power Parity}

Purchasing Power Parity (PPP) is a theory of exchange rate determination. The PPP proposition asserts that differences in relative prices in two countries move together with nominal exchange rates in the long run.

$\mathrm{q}_{\mathrm{t}}=\mathrm{e}_{\mathrm{t}}-\mathrm{p}_{\mathrm{t}}+\mathrm{p}_{\mathrm{t}}{ }^{*}$

$\mathrm{e}_{\mathrm{t}}, \mathrm{p}_{\mathrm{t}}, \mathrm{p}_{\mathrm{t}}{ }^{*}$ denote the logarithms of the nominal exchange rate, domestic price level and foreign price level at time t. To test the random walk hypothesis we used following equation. PPP holds only when the real exchange rate is stationary in this equation.

$$
\mathrm{q}_{\mathrm{t}}=\alpha+\rho \mathrm{q}_{\mathrm{t}-1}+\mathrm{u}_{\mathrm{t}}
$$

PPP does not hold in the long run in the presence of unit root in the real exchange rate series. If the PPP holds, it indicates that nominal exchange rate revised for inflation differences. There are many macroeconomic implications in the case of non-stationarity in real exchange rates. For example, Dornbusch (1987) remarked that real exchange rate depreciation can increase international competitiveness of country, shifting the employment from appreciating country to the other country. Besides that, PPP is an essential element for the establishing the level of an exchange rate.

\section{Data and Empirical Methodology}

\section{Data}

In this paper Augmented Dickey Fuller (ADF), Kwiatkowski-Phillips-Schmidt-Shin (KPSS) and panel unit root tests are employed. Before applying panel unit root tests for the series, heterogeneity and cross sectional dependence tests are used. The annual data set covers for the panel test covers the period from 2000 to 2011 . For the ADF and KPSS tests are used different periods because of the data availability. The critical values for the rejection of the null hypothesis of a unit root are those computed according to the McKinnon criterion (1991). The lag length for the ADF test is based on the akaike information criteria.. The sample period of Belarus and Georgia is 1996M1-2013M11; for Kyrgyzstan 2000M1-2013M9; for Kazakhstan 1995M1-2013M10 for Russia 1994M1-2013M06 and for Armenia 1997M1-2013M10. All data is collected from the Central Bank of the selected countries. The exchange rate regime of Armenia is floating, for Belarus, Georgia, Kyrgyzstan and Russia is managed float and for Kazakhstan is pegged to US dollar. All variables are converted into natural logarithm

An Augmented Dickey-Fuller (ADF) test is a version of the Dickey-Fuller test for a larger and more complicated set of time series models. ADF test has been developed to test univariate time series for the presence of unit roots or non-stationarity. ADF test can be expressed as:

$$
\Delta Y_{t}=\mu+\gamma Y_{t-1}+\sum_{j=1}^{p} \alpha_{j} \Delta Y_{t-j}+\beta t+\omega_{t}
$$

where $\mu$ is the drift term, $t$ denotes the time trend, and $p$ is the largest lag length used. The null hypothesis and alternative hypothesis of the Augmented Dickey-Fuller t-test are:

$$
\begin{aligned}
& H_{0}: \gamma=0 \\
& H_{1}: \gamma=0
\end{aligned}
$$


If $H_{0}$ is rejected we simply conclude that $Y_{t}$ does not contain a unit root. Kwiatkowski, Phillips, Schmidt and Shin (KPSS) developed a unit root test. This test's null hypothesis is different from others and shows the stationarity. If $H_{0}$ is rejected we simply conclude that $Y_{t}$ does contain a unit root.

\begin{tabular}{|c|c|c|c|c|c|c|c|c|}
\hline \multirow[b]{3}{*}{ Variables } & \multicolumn{6}{|c|}{ ADF } & & \\
\hline & \multicolumn{2}{|c|}{ Model A } & \multicolumn{2}{|c|}{ Model B } & \multicolumn{2}{|c|}{ Model C } & \multicolumn{2}{|c|}{ KPSS } \\
\hline & $k$ & $t_{(\gamma)}$ & $k$ & $t_{(\gamma)}$ & $k$ & $t(\gamma)$ & $\eta_{\mu}$ & $\eta_{\tau}$ \\
\hline Armenia & 0 & $-2.25^{* * * *}$ & 0 & $-1.66^{* *}$ & 0 & $0.29^{* *}$ & $0.84^{* * * *}$ & $0.16^{* * *}$ \\
\hline Belarus & 1 & $-2.26^{* * *}$ & 1 & $-2.57^{* *}$ & 1 & $-1.08^{* *}$ & $0.42^{* * *}$ & $0.27^{* * *}$ \\
\hline Georgia & 1 & $-2.06^{* * *}$ & 1 & $-0.64^{* *}$ & 1 & $0.69^{\text {** }}$ & $1.38^{* * *}$ & $0.30^{* * *}$ \\
\hline Kazakhstan & 7 & $-2.40^{* * * *}$ & 7 & $-2.14^{* *}$ & 7 & $0.37^{* *}$ & $0.53^{\text {**** }}$ & $0.16^{* * * *}$ \\
\hline Kyrgyzstan & 1 & $-2.33^{* * * *}$ & 2 & $-0.97^{* * *}$ & 2 & $1.90^{* * *}$ & $1.51^{* * *}$ & $0.13^{* *}$ \\
\hline Russia & 0 & $-5.67^{* * *}$ & 0 & $-5.72^{* * *}$ & 0 & $-5.66^{* * * *}$ & $0.06^{* *}$ & $0.06^{* *}$ \\
\hline $\begin{array}{ll}\text { Critical } \quad(* * *)\end{array}$ & $1 \%$ & $-4.06^{* *}$ & & -3.50 & & -2.59 & 0.74 & 0.21 \\
\hline Value $\quad(* *)$ & $5 \%$ & $-3.46^{* *}$ & & -2.89 & & -1.95 & 0.46 & 0.14 \\
\hline$(*)$ & $10 \%$ & $-3.15^{* *}$ & & -2.58 & & -1.61 & 0.34 & 0.11 \\
\hline
\end{tabular}

Table 1. ADF and KPSS Unit Root Tests

Tables 1 reports the results of these two conventional unit root tests for real exchange rates using ADF, and the KPSS tests. ADF test results indicate that the real exchange rates are non-stationary for Armenia, Belarus, Georgia, Kazakhstan and Kyrgyzstan that is inconsistent with PPP proposition. However, for Russia the real exchange rate series is stationary at all significant level. KPSS test results are consistent with ADF.

\begin{tabular}{|c|c|}
\hline Variable & Test Statistics \\
\hline $\mathrm{P}$ & $24.197 * * *$ \\
\hline
\end{tabular}

Table 2. Cross Sectional Dependence Test ( $C D_{L M}$ Test)

Before implementing the unit root tests, firstly we determine the cross sectional independence between variables. To test cross section dependence, test statistics is computed as follows Pesaran (2004):

$C D=\sqrt{\frac{2 T}{N(N-1)}}\left(\sum_{i=1}^{N-1} \sum_{j=i+1}^{N} \hat{\rho}_{i j}\right)$

$C D$ statistic of Pesaran has mean zero for fixed values of $T$ and $N$, where $N$ indicates cross section dimension, $T$ is time dimension of panel, $\hat{\rho}_{i j}$ represents the sample estimate of the cross sectional correlations among residuals. The hypothesis for the computed test statistics are:

$$
\begin{aligned}
& H_{0}: \rho_{i j}=\rho_{j i}=\operatorname{cor}\left(\varepsilon_{2, i t}, \varepsilon_{2, j t}\right)=0 \\
& H_{1}: \rho_{i j}=\rho_{j i} \neq 0
\end{aligned}
$$

According to Table 2 there is a cross sectional dependence between series in the case of the null hypothesis is rejected. Therefore, it requires to use the unit root test which take into consideration of the cross sectional dependence. Otherwise, the results will be biased. Covariate Augmented Dickey-Fuller (CADF) test of Pesaran can be used as a unit root test under the cross section dependence. The null and alternative hypotheses of the CADF test are shown below:

$$
\begin{aligned}
& H_{0}: \beta_{j}=0 \\
& H_{1}: \beta_{j}<0 \quad j=1,2, . ., N_{1} ; \beta_{j}=0, j=N_{1}+1, N_{1}+2, \ldots, N
\end{aligned}
$$

where $N$ indicates number of cross sections. CADF regression is shown below Pesaran (2007):

$$
\Delta y_{i t}=a_{i}+b_{i} y_{i, t-1}+c_{i} \bar{y}_{t-1}+d_{i} \Delta \bar{y}_{t}+e_{1, i t}
$$

where $\Delta y_{i t}=y_{i t}-y_{i, t-1} ; y_{i, t-1}$ is the first lag of $y_{i t} ; \Delta \bar{y}_{t}$ is cross-section mean of $\Delta y_{t}$ and $e_{1, i t}$ is residuals. The computed test statistics require to be compared with Pesaran (2007) table values. 


\begin{tabular}{|l|c|c|}
\hline \multicolumn{1}{|c|}{ Countries } & CADF & LAGS \\
\hline Belarus & -22.089 & 2 \\
\hline Armenia & -18.733 & 3 \\
\hline Georgia & -2.411 & 3 \\
\hline Kazakhstan & -28.699 & 2 \\
\hline Kyrgyzstan & -24.348 & 2 \\
\hline Russia & -37.686 & 2 \\
\hline
\end{tabular}

Table 3: CADF Test Results

Table 3 shows that null hypothesis of non-stationary is not rejected at $1 \%, 5 \%, 10 \%$ levels and there is a unit root for all countries except Russia. For Russia at $\% 1$ level there is not a unit root but $\% 5$ and $\% 10$ levels there seems to have a unit root. CADF test results are consistent with ADF and KPSS test results. As regards all test results PPP does not hold for all countries excluding Russia.

\section{Conclusion}

In this study the validity of the PPP hypothesis examined for six CIS countries. Long-run validity of the PPP was tested by stationary of the real exchange rate series by employing ADF, KPSS and panel unit root tests. ADF and KPPS indicate that PPP cannot be accepted for the countries except for Russia. According to the panel unit root test results indicate that PPP does not hold for Armenia, Belarus, Georgia, Kazakhstan and Kyrgyzstan except for Russia. There are many macroeconomic implications in the case of non-stationarity in real exchange rates. For example, Dornbusch (1987) remarked that real exchange rate depreciation can increase international competitiveness of country, shifting the employment from appreciating country to the other country. Besides that, PPP is an essential element for the establishing the level of an exchange rate. In addition, Halpern and Wyplosz (1997) indicate that as the service sector suppressed under the command economy, the raising of services can lead to real exchange rate appreciation of country during the transition. Further, this paper will be expanded with the tests taking into consideration of structural changes for these countries.

\section{References}

- Acaravci, A., \& Ozturk, I. 2010. Testing purchasing power parity in transition countries: evidence from structural breaks. Amfiteatru economic, 27, 190-198.

- Apergis, N. 2003. Testing Purchasing Power Parity: results from a new foreign exchange market. Applied economics letters, 10, 91-95.

- Barlow, D. 2003. Purchasing power parity in three transition economies. Economics of Planning, 36, 201221.

- Bekő, J., \& Boršič, D. 2007. Purchasing power parity in transition economies: does it hold in the Czech Republic, Hungary and Slovenia?. Post-communist economies, 19, 417-432.

- Chang, T., Chiu, C. C., \& Tzeng, H. W. 2011. Revisiting purchasing power parity For nine transition countries using the rank test for nonlinear cointegration. Romanian Journal of Economic Forecasting, 2, 1930.

- Chang, T., \& Tzeng, H. W. 2011. Long-run purchasing power parity with asymmetric adjustment: Further evidence from nine transition countries. Economic Modelling, 28, 1383-1391.

- Choudhry, T. 1999. Purchasing power parity in high-inflation Eastern European countries: Evidence from fractional and Harris-Inder cointegration tests. Journal of macroeconomics, 21, 293-308.

- Doğanlar, M. 2006. Long-run validity of Purchasing Power Parity and cointegration analysis for Central Asian countries. Applied economics letters, 13, 457-461.

- Dickey, D A. and Fuller, W. A. 1981. Likelihood Ratio Statics for Autoregressive Time Series with a Unit Root. Econometrica, 49, 1057-1072.

- Doganlar, M. 1999. Testing long-run validity of purchasing power parity for Asian countries. Applied Economic Letters, 6, 147-51.

- $\quad$ Dornbusch, R. 1985. Purchasing power parity. National Bureau of Economic Research, 1591.

- Halpern, L. and Wyplosz, C. 1997. Equilibrium exchange rates in transition economies. IMF Staff Papers, 44, 430-461.

- He, H., Ranjbar, O., \& Chang, T. 2013. Purchasing power parity in transition countries: Old wine with new bottle. Japan and the World Economy, 28, 24-32.

- Hung, S. H., \& Weng, M. J. 2011. Panel unit root tests of purchasing power parity for Central Asian countries. Applied Economics Letters, 18, 585-590. 
- $\quad$ Kwiatkowski, D., Philiphs, P. C.B., Schmidt, P. \& Shin, Y. 1992. Testing the Null Hypothesis of Stationarity Against the Alternative of a Unit Root, How sure are we that Economic Time Series have a Unit Root. Journal of Econometrics, 54, 159-178.

- MacDonald, R., Taylor, M.P. 1992. Exchange rate economics: a survey. Staff Papers - International Monetary Fund, 39, 1-57.

- McKinnon RI .1991. Critical values for cointegration tests. In: Engle RF, Granger CWJ (eds) Long-run economic relationships: reading in cointegration. Oxford University Press, Oxford, 267-276

- $\quad$ Lothian, J.R., Taylor, M.P. 2000. Purchasing power parity over two centuries: strengthening the case for real exchange rate stability reply to Cuddington and Liang. Journal of International Money and Finance, 19,759-764.

- $\quad$ Lu, Y. C. R., Chang, T., \& Lee, C. H. 2012. Nonlinear adjustment to purchasing power parity in transition countries: The ADL test for threshold cointegration. Applied Economics Letters, 19, 629-633.

- Payne, J., Lee, J., \& Hofler, R. 2005. Purchasing power parity: Evidence from a transition economy. Journal of Policy Modeling, 27, 665-672.

- Peseran, M. H. 2004. General Diagnostic Tests for Cross Section Dependence in Panels. IZA Discussion Paper, 1240, 1-39.

- Peseran, M. H. 2006. Estimation and Inference in Large Heterogeneous Panels with a Multifactor Error Structure. Econometrica, 74, 967-1012.

- Peseran, M. H. 2007. A Simple Panel Unit Root Test in the Presence of Cross-Section Dependence. Journal of Applied Econometrics, 22, 265-312.

- $\quad$ Peseran, M. H. and Yamagata, T. 2008. Testing Slope Homogeneity in Large Panels. Journal of Econometrics, 142, 50-93.

- $\quad$ Rogoff, K. 1996. The purchasing power parity puzzle. Journal of Economic Literature, 34, 647-668.

- Sarno, L., Taylor, M.P. 2002. Purchasing power parity and the real exchange rate. IMF Staff Papers, 49, 65105 .

- $\quad$ Sideris, D. 2006. Purchasing power parity in economies in transition: evidence from Central and East European countries. Applied Financial Economics, 16, 135-143.

- Solakoglu, E. G. 2006. Testing purchasing power parity hypothesis for transition economies. Applied financial economics, 16, 561-568.

- Varamini, H., \& Lisachuk, H. G. 1998. The application of purchasing-power parity to Ukraine by using the cointegration approach. Russian and East European finance and trade, 60-69.

- Taylor, M.P., 1995. The economics of exchange-rates. Journal of Economic Literature, 33, $13-47$.

- Taylor, M.P., Sarno, L., 1998. The behavior of real exchange rates during the post- Bretton Woods period. Journal of International Economics, 46, 281-312.

- $\quad$ Taylor, A. M. and Taylor, M. P. 2004. The purchasing power parity debate, Journal of Economic Perspectives, 18, 135-58.

- Taylor, M.P., 2004. Is official exchange rate intervention effective? Economica, 71, 1-11.

- Telatar, E., \& Hasanov, M. 2009. Purchasing power parity in Central and East European countries. Eastern European Economics, 47, 25-41.

- $\quad$ Tkalec, M., \& Vizek, M. 2011. Purchasing power parity in a transition country: The case of Croatia. Comparative Economic Studies, 53, 223-238. 